\title{
IMPLEMENTING A LANDSCAPE EDUCATIONAL Project Among Greek Pupils: VAluable LESSONS AND HARD REALIZATIONS
}

\author{
Ioanna Siama, Theano S. Terkenli and Aikaterini Klonari \\ Department of Geography, University of the Aegean, Lesvos, Greece
}

\begin{abstract}
This paper presents and assesses the implementation of a landscape educational project for schoolchildren in Greece, where landscape awareness is inadequate. Specifically, the project was implemented in a sample of 239 kindergarten, first-grade and sixth-grade primary school children, in different regions of Greece. Children's emotional, behavioural and cognitive relationship with the landscape was first evaluated, through an in-depth questionnaire. Next, children participated in a series of interactive experiential activities, for the purposes of awareness-raising and familiarization with the landscape. Finally, the project's efficiency was evaluated through another questionnaire, building on the initial one. Following the project's implementation, children's landscape conceptualizations and behavioral interrelations with it appear broadened and nuanced with age. However, deeply-rooted cultural views about the landscape seem to persist in the children's emotional rapport with their landscapes, notwithstanding the fact that such educational projects ought to be adjusted to the their specific spatio-temporal and cultural contexts.
\end{abstract}

\section{KEYWORDS}

landscape, landscape perception, landscape education, educational project, pupils' perception .

\section{INTRODUCTION}

Greece is generally considered to be one of the least landscape-conscious among European countries, still lagging in terms of the implementation of the European Landscape Convention (ELC) (Terkenli \& Pavlis, 2012) and, thus, in need of further and more concerted landscape education. Amongst other recommended measures, the ELC (Council of Europe, 2000) underlines the importance of raising people's landscape awareness (Article 6a) as well as the significance of educating people regarding landscape issues, irrespective of age, through "school and university courses which, in the relevant subject areas, address the values attaching to landscapes and the issues raised by their protection, management and planning" (Article 6c, p. 4).

According to relevant scientific research, landscape education should ideally start with the younger ages - those most malleable, in terms of shaping perceptions and consciousness vis-à-vis the landscape (Witt \& Kimple, 2006). Therefore, based on the particularities of the current educational system in Greece, the objective of this paper is to design and implement a comprehensive landscape educational project for Greek schoolchildren, and specifically kindergarten and the first and sixth grades of primary school. The paper purports to investigate changes in children's perceptions, emotions and behavior regarding the landscape, after their participation in the proposed 3-step educational project. 
This research is conducted in the broader context of contributing to the fulfilment of Greece's obligations towards the implementation of the ELC, by catering to the inadequacies of the Greek educational system as regards landscape education. The overarching value of the study lies in the prospect that the enrichment of the national educational system with such an educational tool will contribute to the long-term development of a landscape culture and conscience in society.

\section{Theoretical Context}

\subsection{The Landscape Concept}

Geographers, and social scientists more broadly, acknowledge that, aside from particular objective features and properties, a landscape is constituted of distinct features and properties and their interrelationships, as they develop in time-space, at both the cultural and subjective or intersubjective levels (Lowenthal, 1961; Meinig, 1979). As part of our everyday life, the landscape reflects human activities and physical transformations, and, vice versa, all parts of the world have by now been affected in one way or another by human activities (Terkenli, 2008). According to the ELC (Council of Europe, 2000), "landscape means an area, as perceived by people, whose character is the result of the action and interaction of natural and/or human factors" (Article 1a). The ELC, thus, establishes that all landscapes are cultural. Moreover, the ELC considers the landscape as an essential component of quality of life and thus makes it clear that landscapes are not only those of high aesthetic value and importance but also ordinary and degraded ones, while urging each country in the process of adopting and implementing the policies and measures proposed by the Convention to take into consideration the country's specific political, economic, natural etc. characteristics and particularities (Dejeant Pons, 2007).

The study of landscape in the scientific field of Geography evolved, in the 1960s, from theretofore descriptive approaches to humanistic, representational and subsequently, in the 1980s, to marxiststructuralist paradigms (Boutoura, 2009). By the late 1970s, postmodernism had made inroads into landscape study and, in the late 1980s-early 1990s, ushered in 'the cultural turn' in the discipline of Geography, thus signaling the return and re-establishment of the study of landscape as one of the most significant integrative areas of geographical research. Accordingly, holistic, composite and integrative epistemologies led to the formulation of a three-fold analytical scheme of interlocking landscape dimensions/ properties: a) landscape forms and structures, b) landscape functions and processes, and c) landscape values and meanings/ symbolisms. All dimensions and properties of the landscape are constantly being shaped by both biological laws and cultural rules, interpreted and applied to the land, through personal and interpersonal/ cultural strategies (Terkenli, 2008). Thus, landscapes vary in time, space and social context and become the most visible and eloquent expressions of variable and evertransforming human-environment relationships (Cosgrove, 1998).

\subsection{Landscape Education}

Appropriate education has been shown to lead to the development of more landscape-sensitized societies and sustainable landscape management, planning and practices (Tilbury, 1994; Wilson, 1994). Gómez-Zotano \& Riesco-Chueca (2010, p. 3) rightly claim that "in a dynamic and complex territory such as Europe, landscape education becomes a crucial issue". We adopt their definition of landscape education as a "process whereby landscape values are recognized, and the concepts and methods are acquired which enable the student to incorporate a landscape-sensitive behavior and attitude" (2010, p. 4). Compared to adults, children often view and interpret the environment in a manner that is more elaborate and personal (Chawla, 1986; Nabhan \& Trimble, 1994). As children become older, their ability to process new information relates to higher cognitive and analytical levels, enabling them to combine data better and take better advantage of pre-acquired knowledge. 
Pre-school experiences seem to be the most important factor in shaping perceptions and assumptions about later life as what occurs during childhood play in wild environments could influence later adult behavior (Bixler, Floyd \& Hammitt, 2002; Measham, 2006). Accordingly, environmental education and, in our opinion, landscape education, ought to begin in the very first years of a human lifetime, and ought to be differentiated by age-level, based on children's everyday life experiences, as they play a key role in shaping attitudes, values and patterns of human behavior vis-à-vis the natural environment, the landscape and the world (Tilbury, 1994; Wilson, 1994). Different educational projects implemented in different contexts (cultural systems, countries, regions, etc.) tend to yield highly variable outcomes (Rubenstein, 2006).

Furthermore, the key in primary school education is to provide direct experience of different landscapes in order to highlight the diversity of landscape components (Pedroli \& Mansvelt, 2006). Moreover, both logical/ perceptual and emotional processes of learning about landscape issues ought to be integrated into educational curricula (Castiglioni, 2009). For our purposes, we adopt a somewhat more analytical three-fold schema/ approach, corresponding to the human hypostasis, according to which the three dimensions of human-landscape interrelations are: a) cognitive (mental, perceptual etc.), b) affective (emotional, psychological etc.), and c) behavioral (experiential, practical etc.). The landscape acquires its distinctive character/ identity through the interplay of all of these, highly interwoven, human ways of relating to and interacting with it (Terkenli, 2008).

\subsection{The Greek Case}

In spite of serious but rather sporadic and disunited recent efforts in tertiary education institutions all over the country, landscape education is still lacking at most levels of the Greek educational system. Due to a series of historical circumstances and socio-cultural factors (Terkenli, 2011), Greece did not have the chance to go through any of the stages of landscape awareness and conscience formation experienced by other European societies (Cosgrove, 1998; Olwig, 2001), such as a Renaissance, a baroque phase or a fully-fledged industrial revolution. In the post-war period, through the rapid urbanization of the 1960s and 1970s, Greek society lost its age-old connections with the land, the countryside and the landscape (Pettifer, 1993; Terkenli \& Pavlis, 2012).

Lay landscape awareness and sensitization have lagged ever since. Indicatively, although European legislation has implemented some actions, since the beginning of the 19th century, regarding the protection of landscapes and their biophysical/ cultural/ aesthetic values (Vlantou, 2010), the Greek landscape's existence was legally acknowledged properly, during the 20th century, only in the context of environmental legislation, e.g. areas of high biological, ecological, aesthetic or geomorphologic values (Terkenli, 2011). Moreover, contrary to most other European countries, Greece does not have a Landscape Department or Directorate at the ministerial level, nor does it have landscape institutions at the regional or local levels (Siama, Terkenli \& Klonari, 2018). The few existing landscape-related educational projects in the country focus mainly on landscapes of great cultural (e.g. archeological sites) or aesthetic value (e.g. 'aesthetic forests', natural environments). Greek primary school textbooks contain few references to the landscape, its various elements and people's interrelationships with it, mostly in the curricula of Geography and Environmental Studies. Specifically, Greek primary school textbooks include references and accounts/ analyses related to landscape, but only in terms of 'natural environment', 'cultural heritage', 'neighborhood', etc., with no mention to landscape per se, as constituted by a series of interwoven and interacting elements, functions and meanings, forming together a whole that is called 'landscape'.

Finally, with regard to the landscape itself, Greece is a country generally characterized by a rich diversity, shaped by a series of physical-geographical and human-geographical particularities, such as its geographical position-specific geomorphology and biogeography, unique culture, history and climate, and human activities often leading to the degradation of its natural and urban landscapes. 
This is mainly due to dubious, inappropriate and unsustainable planning and construction practices; illegal, out-of-scale and out-of-plan urban sprawl and tourism/ recreational development; and a general lack of an aesthetic culture and landscape awareness and sensitization. We uphold the ELC's premise that any attempts towards the sustainable planning/ management/ protection of the Greek landscape ought to be based on knowledge and education, but also on active public/ citizen participation in decision-making processes (Wascher 2001; Vogiatzakis, Pungetti \& Mannion, 2008; Terkenli \& Pavlis, 2012).

\section{RESEARCH DESIGN AND METHODOLOGY}

In order to ascertain existing deficiencies and gaps relating to landscape education, training and awareness/ sensitization in Greece, we first undertook a thorough critical literature review of the relevant scientific literature, of best existing practices in landscape education, at the national and international levels, and of the Greek educational system.

Based on the findings of this review, we designed a landscape educational project, emphasizing the activation of the cognitive - emotional - behavioral nexus of preschool and primary school children's landscape notions and practices. Nonetheless, we concede that all of the latter occur within the context of case-specific cultural and family options, norms, habits, rules, restrictions and practices. Our two main research hypotheses were formulated as follows:

H 1. Before the implementation of the landscape educational project, all children — and especially the younger ones - were expected to exhibit a narrow (limited) perception of the concept of landscape, and their associated views and opinions were expected to pertain mostly to the natural environment (landscape as 'nature') or to aesthetically pleasing views (landscape as 'beauty').

H 2. After the implementation of the landscape educational project, all children were expected to exhibit changed views and perceptions towards the landscape, at all levels (emotional, cognitive and behavioral). We expected that this change would not be of the same degree for each of the three different age groups.

The proposed landscape educational project comprised three stages, all of which were implemented in class, during designated class modules:

(1) a questionnaire survey in a sample of preschools and primary schools,

(2) implementation of a series of specific interactive/ experiential educational

(3) activities and

(4) a questionnaire evaluating the change in children's attitudes, opinions, values and behavior towards the landscape after the educational project, as well as the efficiency, accuracy and reliability of the project.

At all stages of the project, children were engaged in experiential and interactive educational activities, encompassing all (cognitive-emotional-behavioral) aspects of their relationship with the landscape - both familiar and broader, both every day and unique, in line with ELC principles — while promoting the values of teamwork and cooperation.

Our data collection tools were designed to be applied specifically to three different age groups: kindergarten, first and sixth grades, and to address the particularities of the Greek educational system and lay culture, vis-à-vis the landscape. Children of the first two age groups were selected because, at these ages, children are extremely malleable concerning landscape awareness and conscience raising, thus their behavior and values may change more readily and spontaneously upon familiarization with 
the educational subject matter. Children of the third age group tend to be less malleable regarding the development of a landscape conscience, as their views and behaviors have normally crystallized more by that age, but still remain quite receptive to training and awareness-raising (Piaget, 1964). Moreover, pupils of this age have just completed primary school and are at a turning point in their education, before proceeding to the next educational level, secondary school. The proposed educational landscape project was similar for all three age groups, except that, in the first and sixth primary school grades, the teaching material was presented in both digital form and analog hardcopy.

Certain biographical parameters were assumed to be influential on the effectiveness of the project, and were, thus, taken into consideration, i.e. socio-economic backgrounds, local landscapes or place of residence and pupils' country of origin. In order for the project to be more bias-free and effective, it was implemented in different areas of the country: urban, rural, coastal and mountainous, and, within our urban survey site, we compensated for broad socio-economic differences by conducting the survey in city districts or suburbs illustrating such variation. In total, we carried out the proposed educational project with 239 children in 9 public kindergartens and 6 public primary schools, in 9 different regions of Greece, during the spring of 2017. 121 kindergarten, 60 first- and 58 sixth-grade children participated in the first stage of the project, whereas 44 kindergarten, 39 first- and 34 sixthgrade children participated in the second and third phases, due to time limitations owing to Ministry of Education permission-acquisition bureaucratic procedures. More specifically, these regions were (Figure 1):

(1) Urban. Prefecture of Attica: Keratsini, Ilioupoli, Paleo Faliro, Argyroupoli and Glyfada

(2) Rural. Prefecture of Larissa: Anavra, Platykampos

(3) Coastal. Prefecture of Lesvos: Nees Kydonies

(4) Mountainous. Prefecture of Lesvos: Agra

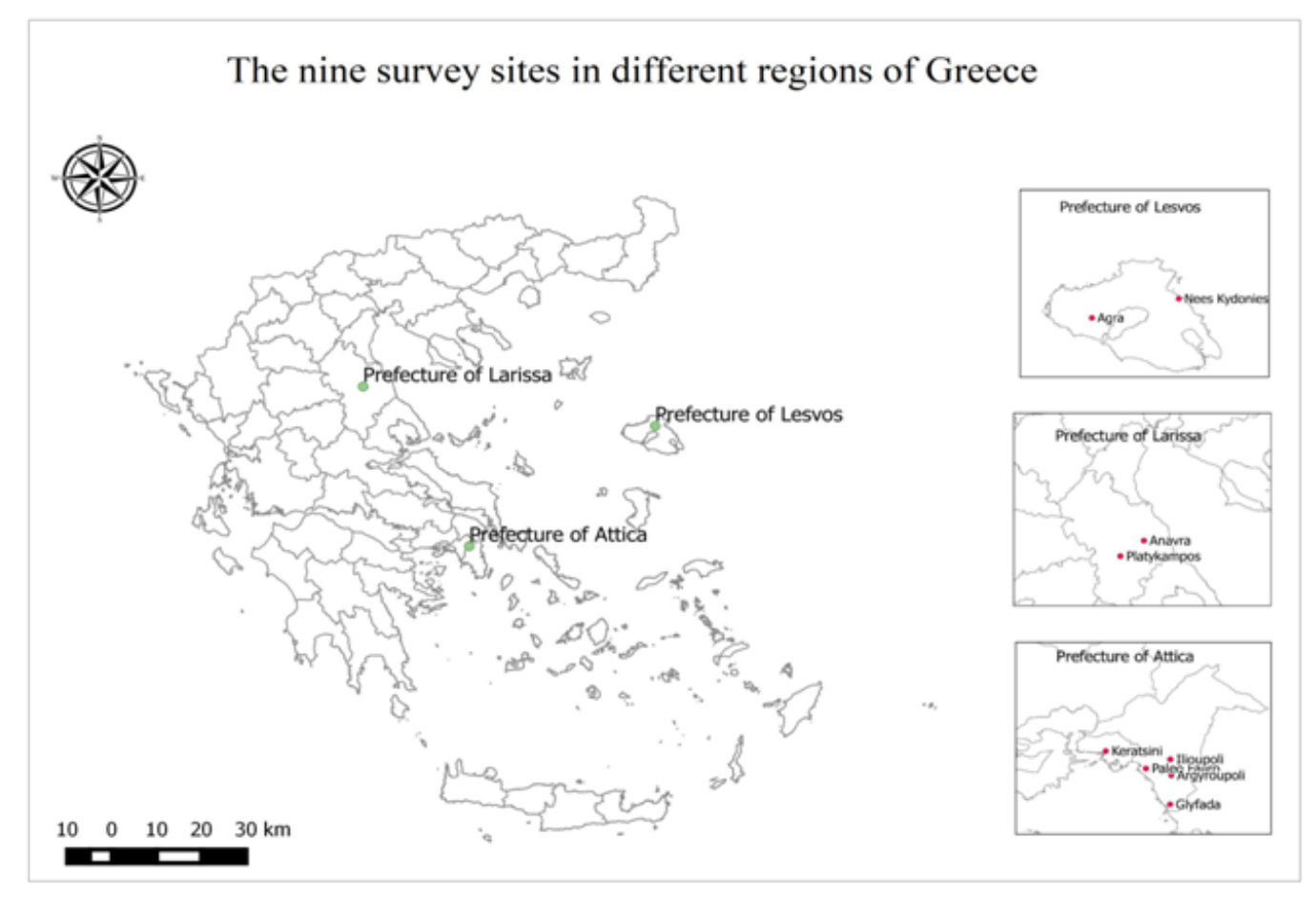

Figure 1. The nine survey sites in different regions of Greece

Most of our sample's children's place of residence was also that of their place of origin (all age groups). Only a few children came from foreign countries (mainly Albania), approximately $10 \%$ of 
our sample, which consisted of both boys and girls, equally distributed in each age group. Furthermore, for the Prefecture of Attica, the project was implemented in both high-income areas (e.g. Glyfada) and comparatively lower-income areas (e.g. Ilioupoli). However, no statistically significant correlations were found among all of the above demographic data and changes in the children's landscape notions and/or attitudes, through the implementation of the project.

\section{Brief OVerview of the Project}

Collectively, the whole educational project was conducted during spring 2017 and lasted a total of eight teaching hours, spread into four 2-hour class meetings, over a period of four consecutive weeks. The duration of each of the three stages varied, depending on the activities it included. The researcher visited, each class (kindergarten, first and sixth grade) of the schools that participated in the project, once a week, and during these times, the researcher, in cooperation with the children and their teachers, conducted the project activities as they are described, in their specific order, below.

\subsection{The First Stage of the Educational Project}

The first stage of the educational project, lasting 2 teaching hours, related to the acquisition of information and data regarding the cognitive/ perceptual, affective and behavioral aspects of the children's overall relationship with the landscapes of their homes, schools and the places where they spend their holidays. The chosen tool was appropriately designed questionnaires with open-ended questions, in order to obtain children's spontaneous and unbiased answers (Filias, 1996; Christou, 2003). For kindergarten and first-grade children, the answers were recorded by the researcher, whereas for the sixth-grade classes answers were written by the children themselves.

In a few words, the questionnaire survey

(1) led to insights about the variable ways in which children of each age group view/ perceive, feel, understand and interact with the landscape, according to their age/class;

(2) helped identify their common perceptions, knowledge, emotions, behaviors and experience, but also the differences, weaknesses and gaps among them, taking into account different independent factors (place of residence, country of providence, cultural background, etc.); and

(3) served in establishing a first understanding of how young children in Greece variably relate to the landscape.

\subsection{The Second Stage of the Educational Project}

The second stage of the project lasted 5 teaching hours in total and included selected educational, experiential activities, interwoven into the framework of an educational process. Education proves more efficient when students acquire procedural knowledge in addition to declarative knowledge, as procedural knowledge offers opportunities for more and different kinds of achievement, due to the fact that this kind of knowledge is more flexible than declarative knowledge (Van Dijk, Van der Schee, Trimp \& Van der Zijpp, 1994). Therefore, children were given the chance to confront landscape issues and, consequently, develop landscape conceptualization and sensitization. First, an instructive discussion with the children introducing them to the subject matter took place, allowing the researcher to form a first view about their cognitive and perceptual interrelations with the landscape. Then followed a video presentation, specifically created for this purpose (https://www.youtube.com/watch?v=HqKA-6zJY8c, English translation of the narration text below the video), in simple but scientifically correct language. Next, a presentation of a series of images presented the concepts of landscape scale and perspective in a clear and illustrative way, accompanied by a real-time experiential task with appealing toys. 
Then came a projection of a series of images in which children engaged in observing and categorizing the different elements composing a landscape (natural/ built environment, activities, people, etc.). Another activity performed at this point was a puzzle-construction game, comprising various landscape images, aiding children to understand the constituent parts of a landscape (natural, human, etc.) and the processes/ interrelationships which link them together, supplemented by open-group inclass discussion. Finally, educational interactive and experiential activities such as improvisation, role-playing games and story-telling were organized and narrated by the children themselves. In this way, children created their own contexts and settings for interaction, pertaining to different landscape elements, dimensions, functions, etc. These were followed by a presentation of photographs of specific landscapes chronologically, illustrating and instructing them about landscape change over time. In the end, children were called to paint their imaginary ideal landscapes.

\subsection{The Third Stage of the Educational Project}

Following the educational activities described above, the children were asked to complete, once again, a questionnaire which built on the initial one (first stage of the project), with the addition of certain supplementary questions, aiming to evaluate changes in children's attitudes, perceptions, emotions, values and behavior towards the landscape, after having participated in the educational project (total time 1 class hour). Furthermore, with the same questionnaire, the children were asked to evaluate the project, so that its shortcomings and disadvantages are revealed and remedied. The two additional questions of this questionnaire were: a) 'What did you like most and what least, in the landscape education project in which you participated, and why?' and b) 'In the future, would you like to participate in a similar training project again and why?'.

\section{Findings: Presentation AND ANALYSIS}

After the implementation of the educational project, statistical analysis (frequency and correlation tests) of pupils' answers in both questionnaires (initial and final ones) was carried out with the aid of SPSS. The values of the variables were decodified and categorized in 2 ways:

(1) Categorization 1: Broader natural environment, Familiar natural environment, People, Familiar built environment, Familiar built environment's elements, Broader built environment, Broader built environment's elements, Activities, Negative answers, Positive answers, Other

(2) Categorization 2: Structures and forms, Functions and processes, Negative answers, Positive answers, Other

In order to investigate children's landscape perceptions and knowledge in relation to their age, and also in order to examine how these were altered after the implementation of the educational project, we first present our conclusions deriving from children's responses to the two questionnaires, separately $\left(1^{\text {st }}\right.$ and $3^{\text {rd }}$ stages of the project). Next, we compare these two groups of responses, but only for the most significant ones out of the total number of questionnaire questions. All of the following data analysis stems from our correlation tests that were statistically significant ( $\mathrm{p} \leq 0.05)$, so that we may be in a position to draw sufficiently reliable conclusions for our sample. 
International Journal of Education (IJE) Vol.8, No.1, March 2020

Table 1. Children's responses to all questions, before and after the implementation of the project.

\begin{tabular}{|c|c|c|c|c|c|c|c|}
\hline \multirow[b]{2}{*}{ Question } & \multicolumn{4}{|c|}{ Pre-project answers } & \multicolumn{3}{|c|}{ Post-project answers } \\
\hline & Variable & $\begin{array}{c}\text { Kinder- } \\
\text { garten }\end{array}$ & $\begin{array}{c}1^{\text {st }} \\
\text { grade }\end{array}$ & $\begin{array}{c}6^{\text {th }} \\
\text { grade }\end{array}$ & $\begin{array}{l}\text { Kinder- } \\
\text { garten }\end{array}$ & $\begin{array}{c}1^{\text {st }} \\
\text { grade }\end{array}$ & $6^{\text {th }}$ grade \\
\hline $\begin{array}{l}\text { 1. What is } \\
\text { there, in the } \\
\text { landscape } \\
\text { around your } \\
\text { home? }\end{array}$ & $\begin{array}{l}\text { BBE } \\
\text { (broader } \\
\text { built } \\
\text { environ- } \\
\text { ment) }\end{array}$ & $61.4 \%$ & $61.5 \%$ & $91.2 \%$ & NS (test & $\begin{array}{l}\text { ults not } \\
\text { gnifican }\end{array}$ & stically \\
\hline \multirow{2}{*}{$\begin{array}{l}\text { 2. What did } \\
\text { you see at the } \\
\text { place where } \\
\text { you last went, } \\
\text { or usually go } \\
\text { to, on your } \\
\text { holidays? }\end{array}$} & $\mathrm{BBE}$ & $22 \%$ & $19.7 \%$ & $61.8 \%$ & & NS & \\
\hline & People & \multicolumn{3}{|c|}{ NS } & $11.8 \%$ & $3.3 \%$ & $37.1 \%$ \\
\hline \multirow{2}{*}{$\begin{array}{l}\text { 3. What do } \\
\text { you think are } \\
\text { the threats to a } \\
\text { landscape? }\end{array}$} & \begin{tabular}{|c|} 
SF \\
(structures \\
and forms)
\end{tabular} & $80 \%$ & $33.3 \%$ & $68.8 \%$ & $25.6 \%$ & $42.5 \%$ & $79.4 \%$ \\
\hline & $\begin{array}{c}\mathrm{PF} \\
\text { (processes } \\
\text { and } \\
\text { functions) }\end{array}$ & $10 \%$ & $46.9 \%$ & $44.4 \%$ & $14 \%$ & $32.5 \%$ & $61.8 \%$ \\
\hline \begin{tabular}{|l|}
4. Besides \\
your home, \\
school, and \\
place(s) of \\
holidays, \\
where else do \\
you spend \\
your free time, \\
and what do \\
you do there?
\end{tabular} & Activities & $52.3 \%$ & $62.2 \%$ & $88.2 \%$ & $38.2 \%$ & $80 \%$ & $91.2 \%$ \\
\hline \multirow[t]{3}{*}{$\begin{array}{l}\text { 5. What } \\
\text { activities do } \\
\text { you do, when } \\
\text { you are on a } \\
\text { holiday? }\end{array}$} & $\begin{array}{c}\text { BNE } \\
\text { (broader } \\
\text { natural } \\
\text { environ- } \\
\text { ment) }\end{array}$ & $75 \%$ & $76.3 \%$ & $47.1 \%$ & $48.4 \%$ & $73.9 \%$ & $27.3 \%$ \\
\hline & Activities & $42.5 \%$ & $39.5 \%$ & $85.3 \%$ & \multicolumn{3}{|c|}{ NS } \\
\hline & People & \multicolumn{3}{|c|}{ NS } & $6.5 \%$ & $17.4 \%$ & $39.4 \%$ \\
\hline
\end{tabular}




\begin{tabular}{|c|c|c|c|c|c|c|c|}
\hline \multirow{3}{*}{$\begin{array}{l}\text { 6.a What do } \\
\text { you like at the } \\
\text { places where } \\
\text { you spend } \\
\text { your free time } \\
\text { outside your } \\
\text { home? }\end{array}$} & \multicolumn{7}{|c|}{ International Journal of Education (IJE) Vol.8, No.1, March 2020} \\
\hline & BNE & $48.5 \%$ & $15.4 \%$ & $36.4 \%$ & $55.6 \%$ & $43.5 \%$ & $19.4 \%$ \\
\hline & Activities & $6.1 \%$ & $15.4 \%$ & $51.5 \%$ & \multicolumn{3}{|c|}{ NS } \\
\hline $\begin{array}{l}\text { 6.b What do } \\
\text { you dislike at } \\
\text { the places } \\
\text { where you } \\
\text { spend your } \\
\text { free time } \\
\text { outside your } \\
\text { home? }\end{array}$ & BBE & $7.1 \%$ & $5.7 \%$ & $41.9 \%$ & \multicolumn{3}{|c|}{ NS } \\
\hline $\begin{array}{l}\text { 6.cWhat do } \\
\text { you like at the } \\
\text { place(s) of } \\
\text { your holiday? }\end{array}$ & BNE & $56.7 \%$ & $58.3 \%$ & $54.5 \%$ & \multicolumn{3}{|c|}{ NS } \\
\hline $\begin{array}{l}\text { 6.d What do } \\
\text { you dislike at } \\
\text { the place(s) of } \\
\text { your holiday? }\end{array}$ & BNE & $29.2 \%$ & $40.5 \%$ & $11.5 \%$ & $65 \%$ & $38.1 \%$ & $27.3 \%$ \\
\hline \multirow{3}{*}{$\begin{array}{l}\text { 7. Which are } \\
\text { your three } \\
\text { most favorite } \\
\text { landscapes and } \\
\text { why? }\end{array}$} & BNE & $51.6 \%$ & $35.9 \%$ & $79.4 \%$ & \multicolumn{3}{|c|}{ NS } \\
\hline & $\begin{array}{l}\mathrm{BBE} \\
\end{array}$ & $16.1 \%$ & $53.8 \%$ & $50 \%$ & \multicolumn{3}{|c|}{ NS } \\
\hline & $\mathrm{PF}$ & \multicolumn{3}{|c|}{ NS } & $19.2 \%$ & $24.1 \%$ & $55.9 \%$ \\
\hline
\end{tabular}

Initially, we investigate children's responses to the questionnaire before the educational project was conducted (Table 1). Based on the children's responses to the first question (question 1, Table 1), it seems that for the majority of the older children in the sample (sixth grade), the built environment of the landscape around their home draws their attention to a great extent. This finding also applies to the younger children in the sample (kindergarten and first grade), but to a much lesser degree. Noticeably, the same seems to hold true for the places where they spend their holidays (question 2, Table 1). On the other hand, the sixth graders seem to have a more complete and broadened landscape perception and, consequently, their answers regarding their holiday landscapes confirm the conclusion that emerges from their answers concerning the landscapes around their homes.

As regards their perceived threats to a landscape (question 3, Table 1), the majority of the younger children (kindergarten) in the sample answered that mainly landscape forms and structures are at risk; only a few of the children of the same age group included landscape processes and functions in their responses to the third question.

In answer to how they choose to spend their free time (question 4, Table 1), children, and especially sixth graders, stated that they mostly engaged in activities (i.e. basketball training, doing martial arts, etc.). Similar responses were given by the first graders (i.e. painting, sports, dancing, etc.), as opposed to Kindergarten children, who often replied that they played outside, in open playgrounds, as is common practice in Greece. As children grow up, such interactions seem to become increasingly 
carried out in systematic, structured and organized ways, in enclosed spaces of their everyday life contexts.

When it comes to holiday activities (question 5, Table 1), according to their answers, children come more into contact with the natural environment/ landscape, than when at home. Again, this was an expected outcome for such a question, since family holidays in Greece tend to mostly take place in destinations close to the sea, the mountains, or the countryside, generally speaking. This percentage seems to be lower for the sixth graders, who also referred to various other non-outdoor activities they said they engaged in while on holiday, i.e. 'when I visit a place for the first time, I usually go to its museums', 'I go to the shops and to the amusement park with my dad and my mom ', 'When I'm on holiday, I play board games with my brother or I paint '. This may indicate that, by that age, they have developed a broader variety of interests, they may have discovered other pastimes, or may have more freedom to make independent choices, vis-à-vis parents' guidance or restrictions. Based on their questionnaire responses, we therefore notice that, as children grow up, either they become less attracted to the natural environment and thus do not include it in their answers, or they seem to realize that the landscape does not equate to the natural environment, but also contains other elements. Indeed, a great percentage of the sixth graders (almost half in the sample) include their own activities in their landscape notions, as opposed to the younger children in the sample.

Children's answers to questions 6a,b,c,d and 7 (Table 1) referring to what they like or dislike in the landscape around their homes or at their holiday places and in their favorite landscapes show that, in general, both natural and built environments figure highly in the responses of all age groups. This also comes as no surprise, as all of these environments feature a strong presence of both the human-made and the natural component - with regard to the latter, they usually refer to ugly or damaged parts of the landscape, e.g. a burnt forest, a dirty beach, etc.

Significantly, however, the highest percentages of children's responses regarding the built environment come from sixth graders; as children grow older, they increasingly acknowledge the built dimension of the landscape (besides the natural one). Similarly, more complete responses regarding children's activities (either in their home or in their holiday landscapes) are reported to a greater extent by sixth graders, confirming, once again, that children of this age cohort understand that a landscape does not consist only of forms/ structures, but also includes processes and functions, as opposed to the younger children in the sample who do not seem to carry such inclusive and holistic landscape notions.

We now proceed to investigate children's responses to the final questionnaire, after the implementation of the educational project (Table 1). Generally speaking, as expected, on the basis of existing bibliography and widespread educational experience, after having participated in the educational project, the older children in the sample (sixth graders) tend to refer less to the natural component of the landscape and seem to have understood that people are part of the landscape to a greater extent than the younger ones, as their answers simply include 'people' more often (question 2, Table 1). This could be an additional indication that, as children grow older, they tend to occupy themselves more in organized activities held in structured built environments, and less so in free-play activities, interacting with nature, the outdoors/ open spaces, parks, etc.

With regard to the dangers threatening a landscape (question 3, Table 1), we notice a gradient of percentages in children's responses for both 'structures/ forms' and 'functions/ processes': as children grow older, these percentages get higher. This trend also probably illustrates how, after participating in the project, the sixth graders had a more well-rounded understanding of the great importance of human responsibility towards landscape integrity, as well as of the great impact of human activities, i.e. 'In short, it is the humans; the cause of a forest's destruction is rarely, for example, the weather'. 
Furthermore, an analysis of the children's verbatim responses to the questions about what they liked or disliked in the landscape (both home and holiday landscapes) (questions 6a,b,c,d, Table 1) equally refer to the 'ugly' elements of both the natural (e.g. 'when the flowers are not blooming') and the built environment (e.g. 'a house in front of mine is hiding the landscape'). Thus, we conclude that children seem to have understood that the landscape is not just a beautiful picture or setting, but rather includes literally anything that exists and evolves around us, indicating a more well-rounded, holistic and complete landscape conceptualization. Table 2 presents the children's responses to the four most central and significant questions, pertaining to the cognitive, the emotional and the behavioral relation of children to their landscapes, before and after the project implementation.

Table 2. Children's responses to the four most central research questions before and after the implementation of the project.

\begin{tabular}{|c|c|c|c|}
\hline Question & Type of answer & Initial questionnaire & Final questionnaire \\
\hline \multirow[b]{3}{*}{$\begin{array}{l}\text { 1. What is there, in the } \\
\text { landscape, around your } \\
\text { home? }\end{array}$} & $\mathrm{SF}$ & $99.1 \%$ & $97.0 \%$ \\
\hline & $\mathrm{PF}$ & $6.0 \%$ & $15.5 \%$ \\
\hline & Other & $0.9 \%$ & $1.0 \%$ \\
\hline \multirow{10}{*}{$\begin{array}{l}\text { 6.a What do you like at } \\
\text { the places where you } \\
\text { spend your free time } \\
\text { outside your home? }\end{array}$} & BNE & $32.4 \%$ & $51.6 \%$ \\
\hline & BBE & $25.7 \%$ & $39.4 \%$ \\
\hline & $\mathrm{BNE}+\mathrm{BBE}$ & $9.5 \%$ & $8.5 \%$ \\
\hline & $\begin{array}{l}\text { FNE (familiar natural } \\
\text { environment) }\end{array}$ & $8.6 \%$ & $7.4 \%$ \\
\hline & $\begin{array}{c}\text { FBE (familiar built } \\
\text { environment) }\end{array}$ & $2.9 \%$ & $6.4 \%$ \\
\hline & FNE + FBE & $1.0 \%$ & $0.0 \%$ \\
\hline & People & $10.5 \%$ & $7.4 \%$ \\
\hline & Activities & $24.8 \%$ & $12.8 \%$ \\
\hline & Everyday life activities & $4.8 \%$ & $1.1 \%$ \\
\hline & Other & $14.3 \%$ & $5.3 \%$ \\
\hline \multirow{7}{*}{$\begin{array}{l}\text { 4. Besides your home, } \\
\text { school, and place(s) of } \\
\text { holidays, where else do } \\
\text { you spend your free } \\
\text { time, and what do you } \\
\text { do there? }\end{array}$} & BNE & $6.1 \%$ & $10.8 \%$ \\
\hline & $\mathrm{BBE}$ & $47.8 \%$ & $54.8 \%$ \\
\hline & FNE & $5.2 \%$ & $11.8 \%$ \\
\hline & FBE & $14.8 \%$ & $26.9 \%$ \\
\hline & People & $26.1 \%$ & $36.6 \%$ \\
\hline & Activities & $66.1 \%$ & $68.8 \%$ \\
\hline & Other & $2.6 \%$ & $2.2 \%$ \\
\hline \multirow{2}{*}{$\begin{array}{l}\text { 7. Which are your three } \\
\text { favorite landscapes and } \\
\text { why? }\end{array}$} & SF & $87.6 \%$ & $89.9 \%$ \\
\hline & $\mathrm{PF}$ & $26.7 \%$ & $34.8 \%$ \\
\hline
\end{tabular}

The first question of this part of our analysis, 'What is there, in the landscape, around your home?' addresses the cognitive aspects of children's relationship to the landscape, seeking to investigate how children observe and perceive the different elements and dimensions making up the landscapes of their neighborhood (question 1, Table 2). As indicated by the results of the statistical analysis for the 
initial questionnaire, children focused more on the structures and forms of the landscape, whereas, after having participated in the educational project, they also referred more to the processes and functions that are part of a landscape ( $10 \%$ increase), indicating that children no longer perceive the landscape as a plain picture, but rather as a living and dynamic set of elements, where they live, interact and generally grow up.

The second question of our analysis (question 6.a, Table 2), 'What do you like in the landscape around your home?', concerning the emotional aspects of children's relationship to the landscape, sought to reveal how children feel towards the landscapes of the places they live in, as well as the ways in which they bond with them. The relevant results show that the percentage of children's responses regarding their broader built environment increased (initial questionnaire: $25.7 \%$, final questionnaire: $39.4 \%$ ) after the project implementation, implying that children realised that the landscape is not just related to the natural environment, a place of unique beauty or a beautiful image, but also encompasses the built environment.

With the third question (question 4, Table 2), 'Besides your home, school, and place(s) of holidays, where else do you spend your free time, and what do you do there?', relating to the behavioral aspects of the children's relationship to the landscape, we had aimed to establish how children effectively interact with the landscapes of their everyday lives. After the project implementation, the percentages of children's responses including activities and people increased relatively to the initial questionnaire: from $66.1 \%$ to $68.8 \%$ (for activities) and from $26.1 \%$ to $36.6 \%$, (for people). Moreover, the percentages pertaining to all the variables (landscape elements) increased, illustrating that children's responses became more inclusive (broader set of behavioral patterns vis-à-vis the landscape).

Answers to the fourth question of our analysis 'Which are your three favorite landscapes and why?' (question 7, Table 2) seemed to complement, if not confirm, the results of the three previous ones, as they comprised all three dimensions/aspects (cognitive - behavioral - emotional) of the children's relationship with the landscape. The percentages of the answers including both 'structures and forms' and 'processes and functions' increased after the implementation of the project, reinforcing the fact that children's landscape perceptions were thus broadened, becoming more inclusive as regards the range of landscape elements/ dimensions (Table 3).

Finally, throughout the course of their participation in the experiential activities of the 2nd stage of the project, it was observed that children gradually became increasingly conscious of and familiar with the landscape concept / meaning. They repeatedly referred to landscape parts or features, in accordance with their verbal responses to the questions of the two questionnaires. For instance, during the story-telling activity, a significant number of the participating children referred to their neighborhood, their family, and/or their school, as well as to their physical and natural landscape components (i.e. the forest, the sea, etc.). Similarly, during the improvisation activity, several children chose to assume roles such as animals, flowers, the sea, a tree etc., namely those they had also referred to in their questionnaire responses. A gradual evolution of landscape consciousness was also observed, through children's paintings, by age: Kindergarten children's paintings had not changed much by the end of the project, although the number of paintings that were exclusively related to the natural environment decreased; first- and sixth-grade children's paintings of the third stage contained more people and activities compared to their paintings at the first stage. Furthermore, half of the sixth graders took scale and perspective into account, when drawing.

All of the above illustrate children's gradual acquisition of landscape awareness and consciousness, in line with their age evolution. Generally, their places of residence did not seem to affect changes in the children's landscape perception. However, in their drawings, children coming from urban areas 
tended to paint more restricted areas (i.e. a neighborhood, a school, etc.), while children of non-urban backgrounds tended to paint more expansive areas (i.e. mountains, sea, meadows etc.).

\section{DisCuSSION AND CONCLUSIONS}

This study was carried out in the context of the broader need to remedy the relative lack of landscape awareness, sensitization and training/education in Greece; it was specifically tailored to the Greek educational system, pupils' needs and other socio-cultural particulars. The paper presented the design and implementation results of a landscape educational project, aimed at instilling landscape knowledge and awareness in Greek preschool and primary school children. Our most significant findings confirmed our hypothesized trend that Greek schoolchildren seem to exhibit rather limited perceptions and emotional connections to the landscapes of their everyday lives. The study represents a comprehensive first attempt at tracing such trends and potentialities, in the case of a country, where no such evidence and research exists, so far.

As regards the project's effectiveness, after its implementation, children's, and especially older children's, landscape conceptualizations and perceptions generally appeared to have become more inclusive and nuanced, while their consciousness of threats, and especially human-induced threats, towards the landscape became broader and more pronounced in their responses. This finding corresponds with Piaget's (1964) four stages of cognitive development (sensorimotor, preoperational, concrete operational and formal operational stage), describing that, as children grow up, they formulate an increasingly complex, abstract, broadened and, at the same time, more accurate concept of their surrounding space and its elements/ dimensions. Furthermore, children's behavioralinterrelating with the landscape also seemed to become more pronounced and inclusive. On the other hand, children's emotional relationship with the landscape did not appear to change with the implementation of the project, thus revealing the deeply-rooted conventional views of Greek society towards its/the landscape. This finding is not in complete accordance with our second research hypothesis, but certainly makes sense on the basis of the ways in which change occurs in human mentality and consciousness: deeply-rooted cultural precepts, affects and practices require long-term and continuous processes of learning or unlearning.

Obviously, changes in children's perceptions, emotions and attitudes towards landscape issues cannot rely just on the implementation of a single - and exploratory, at that-landscape educational project, even if included in the school curriculum, because such a change needs to be framed by continuous and systematic effort at the personal, familial, pedagogical and wider societal levels, as 'findings seem to point out that everyday life experiences play a positive role in the formation of lay attitudes toward local environments and landscapes' (Klonari, Dalaka \& Petanidou, 2011). Nonetheless, this study's findings may be useful in supporting new relevant landscape policy, aiding the implementation of the ELC in Greece, instigating citizen education, and eliciting participatory landscape governance, by fostering landscape education more broadly, at all levels of the Greek educational system. Finally, the implementation of any such educational project ought to be tailored to its socio-cultural context, since it is expected to yield different outcomes, depending on the children's particular ways of interrelating with their landscapes, under variable time-space-culture life circumstances.

\section{REFERENCES}

[1] Bixler, R., Floyd, M. \& Hammitt, W. (2002) "Environmental socialization- Quantitative tests of the childhood play hypothesis". Environment and Behaviour Vol. 34, pp795-818.

[2] Boutoura, K. (2009) Critical theory in Geography. School of Rural and Surveying Engineering, Aristotle University of Thessaloniki, Thessaloniki. 
International Journal of Education (IJE) Vol.8, No.1, March 2020

[3] Castiglioni, B. (2009) "Education on landscape for children”. Strasbourg: Council of Europe Report.

[4] Chawla, L. (1986) “The ecology of environmental memory”. Children's Environments Quarterly, Vol. 3, No. 4, pp34-42.

[5] Christou, E. (2003) Market Research. University teaching notes. Chios: Department of Business Administration.

[6] Cosgrove, D. (1998) “Cultural landscapes” In Unwin, T. (Ed), A European geography, pp65-81, London: Longman.

[7] Council of Europe (2000) The European Landscape Convention of the Council of Europe. Florence, Italy.

[8] Dejeant-Pons, M. (2007) “The European Landscape Convention” In Beriatos, E., Ballesta, (2007). Theory and landscape policy. Volos, Greece: University of Thessaly.

[9] Filias, V. (1996) Introduction to Methodology and Techniques of Social Sciences (2nd ed.). Athens: Gutenberg.

[10] Gómez-Zotano, J. \& Riesco-Chueca, P. (2010) "Landscape learning and teaching: Innovations in the context of the European Landscape Convention". Proceedings of the INTED2010 Conference. Valencia, Spain.

[11] Klonari, Aik., Dalaka, An. \& Petanidou, Th. (2011) 'How evident is the apparent? Students' and teachers' perceptions of the terraced landscape", International Research in Geographical and Environmental Education, Vol. 20, No. 1, pp5-20.

[12] Lowenthal, D. (1961) "Geography, experience and imagination: towards a geographical epistemology". Annals of the AAG, Vol. 51, pp241-260.

[13] Measham, T. (2006) "Learning about environments: The significance of primal landscapes". Environmental Management, Vol. 38, pp426-434.

[14] Meinig D. W. (Ed) (1979) The interpretation of ordinary landscapes: Geographical Essays. Oxford: Oxford University Press.

[15] Nabhan, G.P. \& Trimble, S. (1994) The Geography of childhood: Why Children Need Wild Places. Boston, MA: Beacon Press.

[16] Olwig, K. (2001) “Landscape as a contested topos of a place, community, and self”. In Adams, Hoelscher, S. \& Till. KE. (Eds), Textures of place: exploring humanist geographies, pp93- 117. Minneapolis, MN: University of Minnesota Press.

[17] Pedroli, B. \& Van Mansvelt, J. D. (2006) "Landscape and awareness-raising, training and education" In Landscape and Sustainable Development: challenges of the European Landscape Convention. Strasbourg: Council of Europe Publishing, pp119-140.

[18] Pettifer, J. (1993) The Greeks: the land and people since the war. London: Penguin

[19] Piaget, J. (1964) “Development and Learning”. Journal of research in science teaching, Vol. 2, pp176-186. Center for Genetic Epistemology. Geneva, Switzerland.

[20] Rubenstein, I. Z. (2006) "Educational Expectations: How They Differ Around the World: Implications for Teaching ESL College Students". Community College Journal of Research and Practice, Vol. 30, No. 5-6, pp433-441. 
[21] Siama, I., Terkenli, T. S. \& Klonari, Aik. (2018) "Building a landscape educational program for the needs of Greek preschool and primary-school children: a methodological approach". Journal of Geography,Vol. 9, No 1, pp80-90.

[22] Terkenli, T. S. (2008) "Understanding and Analyzing Cultural Landscapes” In Conrad, E. \& Cassar, L. F., (Ed). Perspectives on Cultural Landscapes of the Maltese Islands. Malta: International Environment Institute, University of Malta.

[23] Terkenli, T. S. (2011) "In search of the Greek landscape: a cultural geography". In Jones, M. \& Stenseke, M. (Eds.). The European Landscape Convention: Challenges of Participation. Dordrecht: Springer Landscape Series.

[24] Terkenli, T. S. \& Pavlis, E. (2012) “Landscape conscience: awareness raising, training and education” In Papayiannis, Th. \& Howard, P. (Eds.). Reclaiming the Greek Landscape. Athens, Greece: Mediterranean Institute for Nature and Anthropos (Med-INA).

[25] Tilbury, D. (1994) “The critical learning years for environmental education” In Wilson, R.A. (Ed.). (1994) Environmental Education at the Early Childhood Level, pp11-13. Washington, DC: North American Association for Environmental Education.

[26] Van Dijk, H., Van der Schee, J., Trimp, H. \& Van der Zijpp, T. (1994) "Map skills and geographical knowledge", International Research in Geographical and Environmental Education, Vol. 3, No. 1, pp6880 .

[27] Vlantou, A. (2010) "Landscape as a subject of legal protection: relationships and contradictions between the rules of law and reality". Law and Nature Journal.

[28] Vogiatzakis, I.N., Pungetti, G. \& Mannion, A.M. (eds) (2008) Mediterranean Island Landscapes: Natural and Cultural Approaches, Dordrecht, Springer.

[29] Wascher, D. (2001) "European landscapes in transition: Levels of intervention" In Threatened Landscapes: Conserving Cultural Environments (2nd ed.). Green \& W. Vos, London: SponＰress, pp129-138.

[30] Wilson, R.A. (Ed.). (1994) Environmental Education at the Early Childhood Level. Washington, DC: North American Association for Environmental Education.

[31] Witt, S. \& Kimple, K. (2006) "How does your garden grow? Teaching preschool children about the environment”. Early Child Development and Care, Vol. 178, No. 1, pp41-48. 